\title{
Action of relaxin on uterine contractions - a review
}

\author{
S. J. Downing* and M. Hollingsworth \\ Smooth Muscle Pharmacology Group, School of Biological Sciences, University of Manchester, \\ Oxford Road, Manchester M13 9PT, UK
}

\section{Action of Relaxin on the Uterus}

Relaxin is a potent, reversible inhibitor of spontaneous uterine contractions in a number of species, including rats, mice, guineapigs, rabbits, sheep and pigs, in vivo and in vitro. The potency of relaxin on the isolated uterus is about $1-5 \mathrm{nmol} \mathrm{l}^{-1}$ (assuming a molecular mass of $6 \mathrm{kDa}$; Table 1); relaxin is therefore one of the most potent uterine relaxants known. The isolated human uterus, however, has been reported to be relatively insensitive to relaxin. Human recombinant relaxin has only recently become available and, therefore, in this review it may be assumed that the studies described were conducted using porcine relaxin unless stated otherwise. Low doses of relaxin selectively reduce the frequency of contractions in rats in vivo and at high doses complete inhibition of myometrial contractions is achieved (Downing and Hollingsworth, 1991, 1992a). The duration of inhibition is related to the dose of relaxin administered. Relaxin has a rapid onset of action in vivo (within 1-2 min of administration of an intravenous dose) and recovery of uterine contractions to control values occurs rapidly after clearance of relaxin from the circulation. The half-life of endogenous relaxin in the circulation of the mid- and late-pregnant rat is 80 and $50 \mathrm{~min}$, respectively (Sherwood et al., 1984) and human relaxin shows half-lifes of 15 and $60 \mathrm{~min}$ for the second and third decay phases in the rat, respectively (Cossum et al., 1992). Similarly, in vitro, uterine contractions are inhibited rapidly upon addition of relaxin to the tissue bath (Wiqvist and Paul, 1958; Bradshaw et al., 1981; Anderson, 1984), and recovery of uterine contractions occurs after relaxin is washed from the bathing medium. Collectively these observations suggest that relaxin interacts with a plasma membrane receptor in the myometrium. Radiolabelled relaxin has been shown to exhibit specific binding to uterine tissue (McMurtry et al., 1978; Cheah and Sherwood, 1980; Mercado-Simmen et al., 1980, 1982a,b; Osheroff et al., 1990, 1992; Yang et al., 1992). Displaceable relaxin binding is localized to the lateral aspect of the uterine horn including the area of the basalis and myometrium (Osheroff et al., 1992). It appears, however, that receptor density is naturally low in relaxin target tissues, rendering isolation and characterization of receptors for relaxin difficult (Yang et al., 1992).

Uterine sensitivity to relaxin as an inhibitor of spontaneous contractions in vivo and in vitro is modulated by oestrogen and progesterone, but the extent of the modulation has varied between studies. After treatment for $48 \mathrm{~h}$ with a low, physiological dose of oestradiol benzoate $\left(0.4 \mathrm{\mu g} \mathrm{kg}^{-1}\right.$ day $\left.^{-1}\right)$, a twofold increase in uterine sensitivity to relaxin was observed (Downing and Hollingsworth, 1992a). Progesterone treatment

*Author for correspondence; present address: Clore Laboratory for Life Sciences, University of Buckingham, Hunter Street, Buckingham MK18 1EG, UK.

Received 20 April 1993. alone had little effect on uterine sensitivity to relaxin, but combined oestrogen and progesterone treatment produced a tenfold increase in myometrial sensitivity to relaxin. Brenner $e t$ al. (1984) reported that progesterone pretreatment of rats in vivo increased the sensitivity of their uteri to relaxin in vitro, although the change in sensitivity was less than twofold. Other studies have indicated that progesterone can synergize with relaxin in vitro as an inhibitor of uterine contractions (Sarosi et al., 1983; MacLennan et al., 1986). The concentrations of progesterone used ( $\left.1 \mu \mathrm{g} \mathrm{ml}^{-1}\right)$, however, also inhibited uterine contractions, thus the resultant effect could simply have been one of addition.

It has been suggested that oestrogen increases the concentration of myometrial relaxin receptors (Mercado-Simmen et al., 1980, 1982a). More recently, Osheroff et al. (1992) reported that the number of relaxin binding sites in uterine tissue was reduced by $53 \%$ in ovariectomized rats and was restored to $90 \%$ of control values after oestrogen treatment of ovariectomized animals. Uptake of radioiodinated relaxin in uterine tissue in vivo was increased twofold over that in ovariectomized control rats by treatment with $0.4 \mu \mathrm{g}$ oestradiol benzoate $\mathrm{kg}^{-1}$ day ${ }^{-1}$ for 2 days (Downing and Hollingsworth, 1993). In contrast, oestradiol benzoate plus progesterone treatment did not increase further uterine uptake of radioiodinated relaxin. This result suggests that the enhanced uterine sensitivity to relaxin as an inhibitor of spontaneous contractions observed after combined oestrogen and progesterone treatment may be due to both more receptors and additional factors such as enhanced signal transduction processes.

Whereas the potency of relaxin as an inhibitor of spontaneous uterine contractions is only moderately enhanced by oestrogen pretreatment, the ability of relaxin to inhibit spasmogen-stimulated contractions in vivo is markedly influenced by oestrogen (Porter et al., 1979, 1981a; Downing and Hollingsworth, 1992b; Table 1). In ovariectomized rats, the potency of relaxin as an inhibitor of uterine contractions driven by oxytocin or prostaglandin $\mathrm{F}_{2 \alpha}$ was markedly reduced compared with its potency as an inhibitor of spontaneous contractions (Fig. 1). After treatment of ovariectomized rats with a low dose of oestradiol benzoate $\left(0.4 \mu \mathrm{g} \mathrm{kg}^{-1}\right)$ for 2 days, the potency of relaxin as an inhibitor of oxytocin-stimulated contractions was similar to its potency for inhibition of spontaneous contractions (Downing and Hollingsworth, 1992b). In vitro, relaxin can reduce contractions stimulated electrically or by oxytocin or prostaglandins in uteri from oestrogen or oestrogen plus progesterone-treated rats (Chamley et al., 1977; Bradshaw et al., 1981; Goldsmith et al., 1989; McGovern et al., 1992). In the absence of oestrogen pretreatment, however, relaxin is ineffective in inhibiting stimulated uterine contractions (Steinetz et al., 1982; Osa et al., 1991). The marked contrast in the influence of oestrogen on the potency of relaxin 
Table 1. Potencies of relaxins from different species against spontaneous and stimulated uterine contractions

\begin{tabular}{|c|c|c|c|c|}
\hline \multicolumn{5}{|l|}{ In vitro } \\
\hline Pig & Pig & Spontaneous & $>50 \mathrm{ng} \mathrm{ml}^{-1}$ & MacLennan et al., 1986 \\
\hline Pig & Rat & Spontaneous & $5 \mathrm{ng} \mathrm{ml}^{-1}$ & Downing and Hollingsworth, 1991 \\
\hline Pig & Mouse O-treated & Spontaneous & $4-16 \mathrm{ng} \mathrm{ml}^{-1}$ & Reinig et al., 1981 \\
\hline Pig & Guinea-pig, O-treated & Spontaneous & $40 \mathrm{ng} \mathrm{ml}^{-1}$ & Reinig et al., 1981 \\
\hline Pig & $\begin{array}{l}\text { Human, nonpregnant, } \\
\text { pregnant }\end{array}$ & Spontaneous & $>10 \mu \mathrm{g} \mathrm{ml}^{-1}$ & MacLennan et al., 1986 \\
\hline Human & $\begin{array}{l}\text { Human, nonpregnant, } \\
\text { pregnant }\end{array}$ & Spontaneous & $\begin{array}{l}\text { Minimal effect up to } 1.3 \mu \mathrm{g} \\
\mathrm{ml}^{-1}\end{array}$ & MacLennan and Grant, 1991 \\
\hline Shark & Mouse, O-treated & Spontaneous & Ineffective, $>160 \mathrm{ng} \mathrm{ml}^{-1}$ & Reinig et al., 1981 \\
\hline Shark & Guinea-pig, O-treated & Spontaneous & $25-100 \mathrm{ng} \mathrm{ml}^{-1}$ & Reinig et al., 1981 \\
\hline \multicolumn{5}{|l|}{ In vivo } \\
\hline \multirow[t]{2}{*}{ Pig } & Rat, ovariectomized & Spontaneous & $10 \mu \mathrm{g} \mathrm{kg}^{-1}$ & Downing and Hollingsworth, 1992a,b \\
\hline & & Oxytocin-stimulated & $>200 \mu \mathrm{g} \mathrm{kg}^{-1}$ & \\
\hline \multirow[t]{2}{*}{ Pig } & Rat, O-treated & Spontaneous & $5 \mu \mathrm{kg}^{-1}$ & Downing and Hollingsworth, 1992a,b \\
\hline & & Oxytocin-stimulated & $10 \mu \mathrm{g} \mathrm{kg}^{-1}$ & \\
\hline Pig & Rat, $\mathrm{O}+\mathrm{P}$-treated & Spontaneous & $1 \mu \mathrm{g} \mathrm{kg}^{-1}$ & Downing and Hollingsworth, 1992a,b \\
\hline Pig & Sheep, O-treated & Spontaneous & about $20 \mu \mathrm{g} \mathrm{kg}^{-1}$ & Porter ef al., 1981b \\
\hline
\end{tabular}

O: oestrogen; $\mathrm{P}$ : progesterone; $\mathrm{IC}_{50}$ value: concentration that produces $50 \%$ inhibition in vitro; $\mathrm{ID}_{50}$ value: dose that produces $50 \%$ inhibition in vivo.

against spasmogen-induced contractions compared with spontaneous contractions suggests that the mechanism of action of relaxin in the two circumstances is different.

There appears to be variation in the potencies of relaxin from different species as inhibitors of uterine contractions (Table 1 ). Porcine relaxin is effective in inhibiting contractions in uterine tissue from most species so far examined, including rats, mice, sheep, pigs, guinea-pigs and rabbits. Shark relaxin inhibits uterine contractions in guinea-pig uterus but is ineffective in uterine tissue from mice (Reinig et al., 1981). Human recombinant relaxin has a lower potency against spontaneous contractions of porcine uterus than has porcine relaxin (MacLennan and Grant, 1991). Human relaxin has been reported to be ineffective in inhibiting contractions of term pregnant human uterus in vitro (MacLennan and Grant, 1991; Petersen et al., 1991). Such variation in potency between species may be due to variation in the amino acid sequence between relaxins (Schwabe and Bullesbach, 1990, for review). A second contributing factor may be the variation in relative importance of relaxin as an inhibitor of uterine contractions during pregnancy. Low sensitivity to relaxin of uteri isolated from pregnant animals may reflect tolerance developed to endogenous relaxin in vivo (see later).

\section{Mechanism of Action of Relaxin}

Relaxin interacts with a uterine plasma membrane receptor. Several possible post-receptor signal-transduction mechanisms for relaxin have been proposed, including generation of cyclic adenosine $3^{\prime} 5^{\prime}$ monophosphate (cAMP), opening of plasma membrane potassium $\left(\mathrm{K}^{+}\right)$channels and changes in intracellular calcium ion $\left(\mathrm{Ca}^{2+}\right)$ concentration (Fig. 2). The last process may be subsequent to earlier events.

Evidence for a role for cAMP in the mediation of the action of relaxin is provided largely from in vitro studies, using uteri from oestrogen-treated rats or myometrial cells in culture. Porcine relaxin increased cAMP concentration in the rat myometrium in a concentration-dependent manner in the presence of phosphodiesterase inhibitors (Judson et al., 1980; Sanborn et al., 1980) and in rat myometrial cells in culture (Hsu et al., 1985). Human recombinant relaxin and relaxin isolated from human corpora lutea increase cAMP concentrations in a concentration-dependent fashion in cultured human endometrial cells (Fei et al., 1990) and in cultured uterine cells from newborn rhesus monkeys (Kramer et al., 1990), again under conditions in which phosphodiesterases are inactivated. Propranolol did not antagonize relaxin-induced generation of cAMP, suggesting that relaxin-stimulable adenylyl cyclase is not linked to myometrial $\beta_{2}$-adrenoceptors (Hsu et al., 1985). The time course of generation of cAMP by relaxin, however, appears to follow mechanical inhibition (Cheah and Sherwood, 1980; Judson et al., 1980; Sanborn et al., 1980; Osa et al., 1991). Activation of cAMP-dependent protein kinase by relaxin was apparent by $30 \mathrm{~s}$ after administration of the hormone and was maximal by 5 min (Kemp and Niall, 1981), again a time course slower than that of mechanical inhibition. 


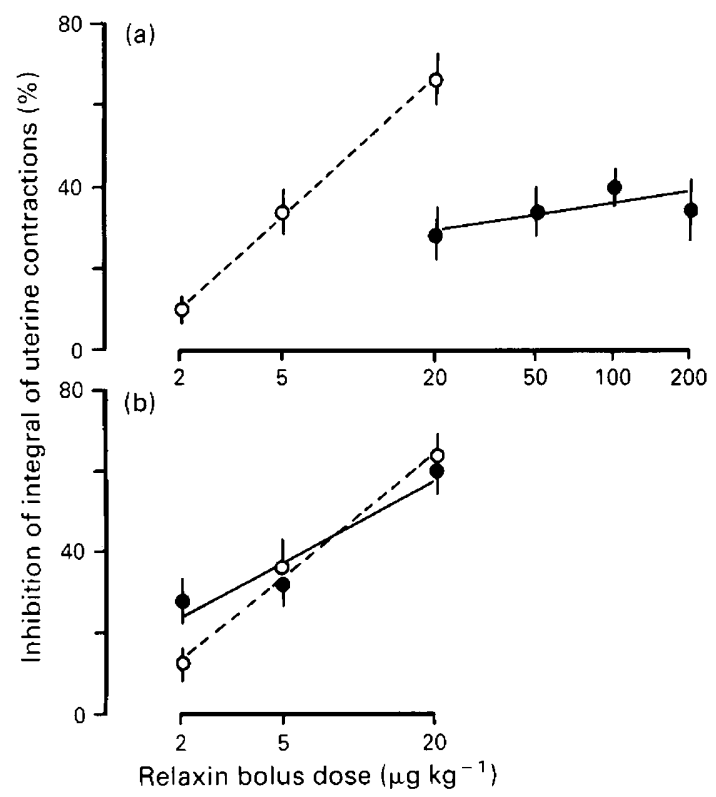

Fig. 1. Dose-response curves for inhibition by relaxin of uterine contractions in (a) vehicle-treated ovariectomized rats (spontaneous contractions $(O)$; oxytocin stimulated contractions $(O) ; 12$ rats) and (b) oestradiol-treated ovariectomized rats (spontaneous contractions $(\mathrm{O})$; oxytocin stimulated contractions $(0)$; 10 rats). Values are means \pm SEM. Ordinate scales: inhibition of integral of uterine contractions over $60 \mathrm{~min}$ as percentage of integral of $60 \mathrm{~min}$ preceding i.v. bolus dose. Abscissa: dose of relaxin on a log scale. (Reprinted with permission from Downing and Hollingsworth, 1992b.)

Evidence for a role for CAMP changes in the action of relaxin on the uterus in vivo is even less convincing. This is particularly apparent when compared with cAMP changes observed after administration of $\beta_{2}$-adrenoceptor agonists, the actions of which are more clearly linked with generation of cAMP (Johansson and Andersson, 1980, 1981). Administration of an i.v. bolus of salbutamol produced a marked (19-fold) increase in uterine CAMP concentrations in the absence of phosphodiesterase inhibitors, in the ovariectomized rat in vivo, for a period of $10 \mathrm{~min}$, followed by a decline in CAMP concentrations (Downing et al., 1992). The time course of inhibition of uterine contractions was correlated with the time course of changes in cAMP concentrations. In contrast, administration of an i.v. bolus of relaxin, which produced a similar marked and prolonged inhibition of uterine contractions, induced only a small increase (threefold) in uterine cAMP concentrations which was of short duration. It is possible that relaxin-induced changes in myometrial cAMP were masked by the presence of the endometrium, or that for relaxin, only small changes in cAMP concentrations are required to bring about the cascade of intracellular events leading to smooth muscle relaxation.

For those agonists for which cAMP is a second messenger, the increased cAMP concentrations are considered to result in activation of CAMP-dependent protein kinase A. This enzyme catalyses phosphorylation of the catalytic subunit of the enzyme myosin light chain kinase (MLCK) (Conti and Adelstein, 1981). Phosphorylation of MLCK reduces its capacity to bind to the calcium-calmodulin complex and, therefore, inhibits formation of the active MLCK-calcium-calmodulin complex required for the phosphorylation (activation) of the $20 \mathrm{kDa}$ light chain of myosin, activation of actin and myosin crossbridges and smooth muscle contraction (Adelstein et al., 1981). Relaxin has been shown to decrease myosin light chain kinase activity and decrease the phosphorylation of myosin light chains in rat uterus (Nishikori et al., 1983; Cole and Garfield, 1986; Hsu and Sanborn, 1986). In addition, the purportedly selective protein kinase $\mathrm{A}$ inhibitor, $\mathrm{H}-8$, reduced the ability of relaxin to inhibit the oxytocin-stimulated rise in intracellular calcium ion concentrations and $\left[{ }^{3} \mathrm{H}\right]$ inositol phosphate formation in rat myometrial cells in culture (Anwer et al., 1990).

A second mechanism by which smooth muscle relaxation can be produced is that of $\mathrm{K}^{+}$channel opening. Drugs known to open potassium channels (e.g. cromakalim) have been shown to cause hyperpolarization of the plasma cell membrane of smooth muscle by opening $\mathrm{K}^{+}$channels (possibly the ATP-sensitive $\mathrm{K}^{+}$channel), such that plasma membrane $\mathrm{Ca}^{2+}$ channels are induced to close (Hamilton et al., 1986; Noack et al., 1992). The influx of $\mathrm{Ca}^{2+}$ via voltage-operated channels is prevented. The reduction in influx of $\mathrm{Ca}^{2+}$ results in low intracellular $\mathrm{Ca}^{2+}$ concentration which, in turn, favours phosphorylation of MLCK. Hyperpolarization of uterine smooth muscle has not been observed for cromakalim (Hollingsworth et al., 1987) or relaxin (Chamley and Parkington, 1984; Osa et al., 1991). It has been suggested, however, that the actions of cromakalim may be limited to opening $\mathrm{K}^{+}$channels in the plasma membrane of pacemaker cells in the myometrium; the hyperpolarization produced would therefore be too localized to be detected by conventional means (Hollingsworth et al., 1987). A characteristic feature of the action of drugs that open $\mathrm{K}^{+}$channels in vitro is that, while they are effective in relaxing a spasm of smooth muscle induced by a low concentration of $\mathrm{KCl}\left(<20 \mathrm{mmol} \mathrm{I}^{-1}\right)$, they are ineffective at relaxing spasm produced by high $\mathrm{KCl}$ concentrations $\left(>40 \mathrm{mmol} \mathrm{l}^{-1}\right)$. This is because, at high $\mathrm{KCl}$ concentrations the plasma membrane is depolarized to such an extent that $\mathrm{Ca}^{2+}$ channels are held open. The hyperpolarization produced by opening $\mathrm{K}^{+}$channels is then insufficient to offset the depolarization induced by the high concentration of $\mathrm{KCl}$. A greater reduction in uterine spasm evoked by low $\mathrm{KCl}$ concentrations than by high $\mathrm{KCl}$ concentrations has been demonstrated in uteri for cromakalim (Piper et al., 1990) and to some extent for relaxin (St-Louis, 1981). Other workers have observed that high concentrations of relaxin are partially effective in reducing uterine spasm induced by high $\mathrm{KCl}$ concentrations (MacLennan et al., 1986; Hughes et al., 1992; Table 1).

It has been reported that the oral hypoglycaemic agent, glibenclamide, is a relatively selective blocker of ATP-sensitive $\mathrm{K}^{+}$channels (Quast and Cook, 1988). In vivo, glibenclamide produced a parallel rightward shift in the dose-response curve for cromakalim as an inhibitor of uterine contractions in ovariectomized rats (Downing and Hollingsworth, 1991). As might be expected, glibenclamide had no effect on uterine sensitivity to the $\beta_{2}$-adrenoceptor agonist, salbutamol. Glibenclamide produced a rightward shift in the dose-response curve for relaxin inhibition of uterine contractions, but in this case, in a non-parallel fashion (Fig. 3). Glibenclamide also reversed an established inhibition of uterine contractions by cromakalim or relaxin but not inhibition induced by salbutamol. 


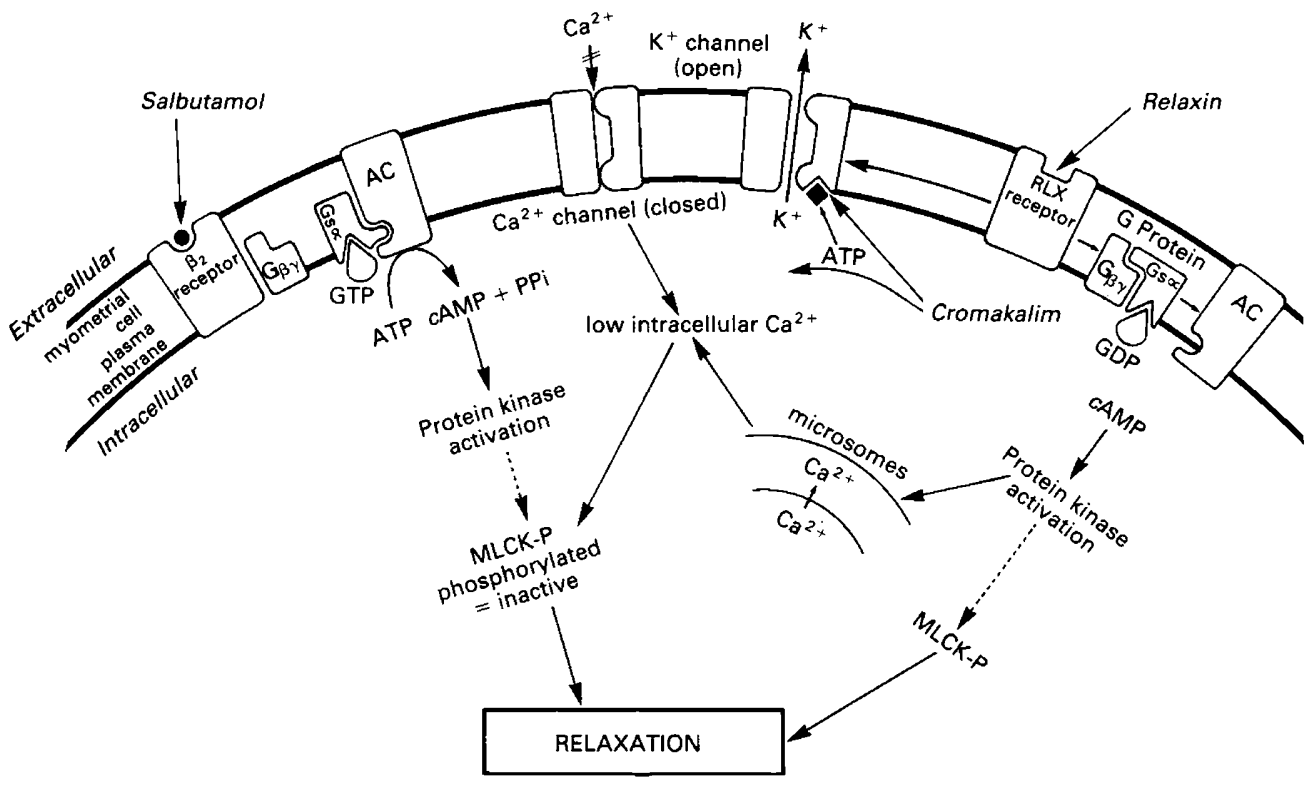

Fig. 2. Schematic representation of the mechanisms of action of the uterine relaxants relaxin, salbutamol (a $\beta_{2}$ adrenoceptor agonist) and cromakalim ( $\mathrm{K} \mathrm{K}^{+}$channel opener) in the myometrial cell. AC: adenylyl cyclase; $\mathrm{G}_{\beta \gamma}$ and $\mathrm{Gs}_{\alpha}$ : subunits of $\mathrm{G}$ protein; $\mathrm{PPi}$ : inorganic phosphate; MLCK-P: phosphorylated myosin light chain kinase; RLX: relaxin; $\beta_{2}$ receptor: $\beta_{2}$ adrenoceptor.

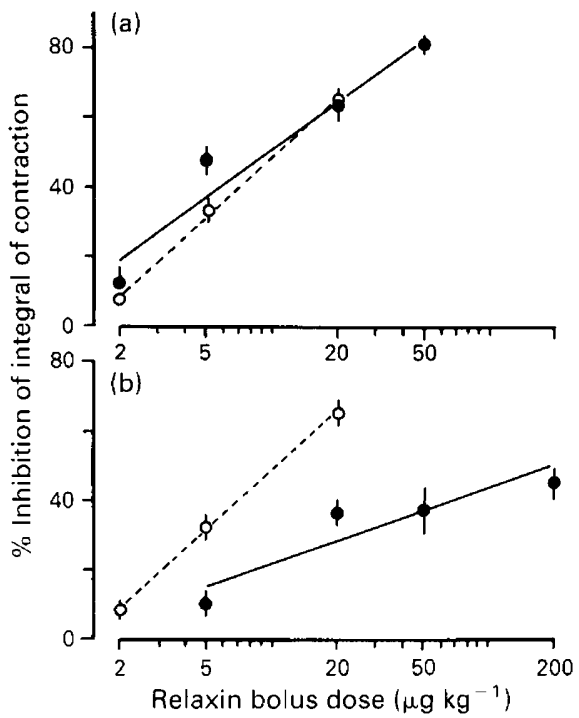

Fig. 3. (a) Effect of relaxin i.v. on uterine contractions in ovariectomized rats before $(O)$ and after (O) infusion of vehicle ( 0.02 mol sodium hydroxide $\mathrm{l}^{-1}$ in $4 \%$ glucose, $5 \mathrm{ml} \mathrm{kg}^{-1}$, i.v.), 40 rats before infusion, 10 rats per point after infusion. (b) Effect of relaxin i.v. on uterine contractions in ovariectomized rats before (O) and after (O) infusion of glibenclamide $\left(20 \mathrm{mg} \mathrm{kg}{ }^{-1}\right.$, i.v.), 40 rats before infusion, 10 rats per point after infusion. Values are means \pm SEM. Ordinate scales: inhibition of integral of uterine contraction over $60 \mathrm{~min}$ as a percentage of integral for $60 \mathrm{~min}$ preceding i.v. relaxin dose. Abscissa scales: dose of relaxin on a log scale. (Reprinted with permission from Downing and Hollingsworth, 1991.)
The results suggest that ATP-sensitive opening of $\mathrm{K}^{+}$channels may be a significant mechanism in the action of relaxin in vivo. In vitro, however, cromakalim was antagonized by glibenclamide as an inhibitor of uterine contractions (Piper et al., 1990), but relaxin was not antagonized (Hughes et al., 1992). This conflict in observations between experiments in vivo and in vitro suggests either that there is an alternative mechanism of action of relaxin in vitro or possibly an additional action of glibenclamide in vivo.

Relaxin increases $\mathrm{Ca}^{2+}$ efflux from rat uterine tissue in vitro (Ginsburg et al., 1988) and in cultured rat myometrial cells (Rao and Sanborn, 1986). Relaxin also inhibits the oxytocin-induced increase of intracellular free $\mathrm{Ca}^{2+}$ concentrations and accumulation of inositol monophosphate, inositol bisphosphate and inositol trisphosphate (Anwer et al., 1989) in cultured rat myometrial cells. These events may be secondary to earlier biochemical or ion channel changes.

In addition to modulation of intracellular events, relaxin may also reduce intercellular communication by reduction of myometrial gap junction permeability (Cole and Garfield, 1986), possibly by a cAMP-dependent mechanism. Such an effect would reduce electrical coupling between myometrial cells and prevent development of strong coordinated contractions.

The involvement of catecholamines as mediators of relaxin action has also been investigated, although with conflicting results. It has been suggested that release of intramural catecholamines contributes to the action of relaxin (St-Louis, 1982) and also that relaxin acts via the myometrial $\beta$ adrenoceptor (Rudzik and Miller, 1962a, b). The lack of antagonism of relaxin by propranolol in vivo (Porter et al., 1979) or in vitro (Sanborn et al., 1981; Chamley and Parkington, 1984) does not substantiate an action of relaxin via $\beta$-adrenoceptors. 
In summary, although increases in cAMP concentrations and $\mathrm{K}^{+}$channel opening may play a part in mediation of inhibition of uterine contractions by relaxin, neither event has been conclusively shown to be solely responsible for the actions of relaxin.

\section{Tolerance}

Relaxin, given as a single i.v. bolus dose, produces rapid inhibition of uterine contractions. It was observed, however, that during continuous, prolonged infusion of relaxin, inhibition of uterine contractions was not maintained and that some return of contractions occurred (Cheah and Sherwood, 1981). Development of tolerance to relaxin as an inhibitor of uterine contractions in vitro has been shown to occur rapidly (Wiqvist, 1959). Tolerance was most pronounced in the longitudinal muscle layer of the myometrium (Chamley and Parkington, 1984), where complete desensitization to relaxin was observed after a single administration. In contrast, the circular muscle layer remained responsive to relaxin upon repeated administration. Administration of porcine relaxin to uterine tissue from nonpregnant rats in vitro resulted in inhibition of spontaneous or electrically driven contractions. Relaxin administered to uterine tissue from late pregnant rats, the endogenous relaxin concentrations of which were high, was, however, ineffective (Porter, 1982) or less potent (Chamley and Parkington, 1984; MacLennan et al., 1986). Injections of porcine relaxin administered twice daily to ovariectomized pregnant rats resulted in reproducible inhibition of uterine contractions throughout the second half of pregnancy (Downing and Sherwood, 1985b), which might suggest that tolerance is not a physiologically relevant phenomenon. The dosage regimen used, however, would have resulted in fluctuating plasma concentrations of relaxin, circumstances under which tolerance would be minimized. The above observations suggest that tolerance to relaxin develops in the uterus upon continued, prolonged exposure to the hormone. More quantitative information on development of tolerance to relaxin has been obtained by Downing and Hollingsworth (1992a). Continuous i.v. infusion of relaxin to ovariectomized rats over $40 \mathrm{~h}\left(20 \mu \mathrm{g} \mathrm{kg}^{-1} \mathrm{~h}^{-1}\right)$ produced a tenfold reduction in uterine sensitivity to relaxin. Partial recovery of uterine sensitivity occurred during the $24 \mathrm{~h}$ following cessation of infusion. The extent of tolerance development is dose dependent since infusion of relaxin at a higher rate $\left(50 \mu \mathrm{g} \mathrm{kg}^{-1} \mathrm{~h}^{-1}\right)$ produced a 130-fold reduction in uterine sensitivity (Fig. 4). Treatment of ovariectomized rats with oestrogen, progesterone or oestrogen plus progesterone did not influence the extent of tolerance developed; however, a more rapid recovery of uterine sensitivity to relaxin after cessation of infusion was observed in oestrogen plus progesterone-treated rats.

It has been suggested that tolerance to other hormones is due to uncoupling of receptors from generation of intracellular second messengers, internalization of membrane receptors or degradation of these receptors. Uterine tolerance to other relaxants, including drugs that open $\mathrm{K}^{+}$channels and $\beta$ adrenoceptor agonists has also been observed in vivo (Abel and Hollingsworth, 1986; Downing and Hollingsworth, 1992a). The mechanism of tolerance to drugs that open $\mathrm{K}^{+}$channels

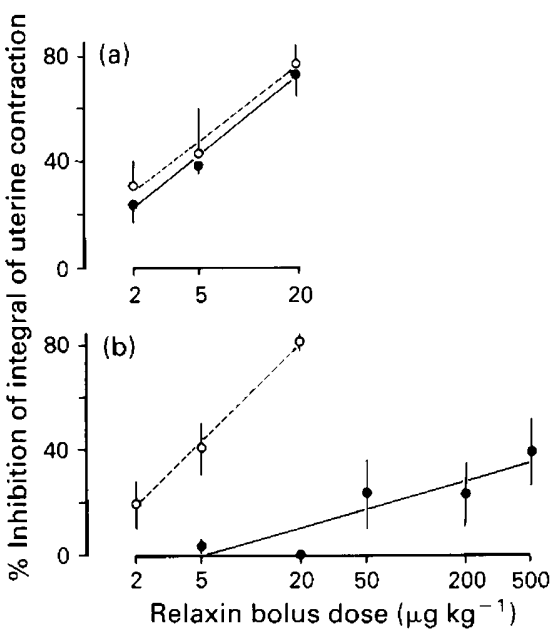

Fig. 4. Dose-response curves for inhibition of uterine contractions by relaxin (a) before $(O)$ and after (O) infusion of saline or (b) before (O) and after (O) infusion of relaxin $\left(50 \mu \mathrm{g} \mathrm{kg}^{-1} \mathrm{~h}^{-1}\right.$ for $\left.40 \mathrm{~h}\right)$ in ovariectomized rats (four rats per dose). Values are means \pm SEM. Ordinate scales: inhibition of integral of uterine contraction over $60 \mathrm{~min}$ as a percentage of integral for $60 \mathrm{~min}$ preceding bolus dose. Abscissa scales: dose of relaxin on a log scale. (Reprinted with permission from Downing and Hollingsworth, 1992a.)

is not known, but tolerance to $\beta$-adrenoceptor agonists has been shown initially to involve phosphorylation of the $\beta$ adrenoceptor with consequent impaired ability of the receptor to couple with adenylyl cyclase (Levitzki, 1986; Lefkowitz et al., 1990). In addition, concomitant with uncoupling of receptors from adenylyl cyclase, $\beta$-adrenoceptors are irreversibly lost from the plasma membrane (downregulation). The lack of crosstolerance among relaxin, cromakalim and salbutamol (Downing and Hollingsworth, 1992a) suggests that the site of tolerance development to relaxin occurs before any common mechanism in the intracellular pathway leading to smooth muscle relaxation. Tolerance to relaxin, therefore, presumably occurs at a relatively early biochemical stage, such as receptor concentration or coupling to second messenger systems. Uterine uptake of radioiodinated relaxin showed little reduction in rats that were tolerant to relaxin compared with relaxin-naive rats, suggesting that for relaxin, tolerance may occur subsequent to its binding (Downing and Hollingsworth, 1993). Studies on the precise mechanism of tolerance to relaxin are still awaited. Tolerance to non-uterine actions of relaxin (e.g. cervical softening) has not been reported suggesting that the biochemical mechanisms underlying uterine relaxation and other effects of relaxin on the reproductive tract differ.

\section{Physiological Functions of Relaxin Action on the Uterus During Pregnancy and Parturition}

The physiological effects of relaxin on the connective tissue of the reproductive tract to promote cervical softening, growth of the interpubic ligament and uterus and development of the mammary gland are important for normal pregnancy and 
parturition in several species (Sherwood, 1988, for review). It has been demonstrated that these effects are essential for normal parturition and live births (Nara et al., 1982; Downing and Sherwood, 1985a; Lao-Guico-Lamm and Sherwood, 1988). The relative importance of relaxin as an inhibitor of uterine contractions varies among species. In some species, such as pigs and rabbits, progesterone is of principal importance for the major part of pregnancy for preventing spontaneous contractions and responses to stimulants such as oxytocin, prostaglandins and stretch imposed on the myometrium owing to the growing fetus (the 'progesterone block', Csapo, 1956; Porter and Watts, 1985). In other species (rats, guinea-pigs) progesterone has little influence on spontaneous uterine contractions (Porter and Challis, 1974). The role of progesterone, if any, as an inhibitor of uterine contractions in humans has not been established.

In species in which progesterone is important in restraining uterine contractions, relaxin may function to prevent the development of uterine contractions during the period of progesterone withdrawal, just before parturition. In pigs, serum relaxin concentrations are low until $48 \mathrm{~h}$ before birth. During this antepartum period, plasma concentrations of relaxin increase rapidly to reach a peak $14 \mathrm{~h}$ before parturition and then decline rapidly to the time of delivery (Sherwood et al., 1975; Watts $e$ t al., 1988). The increased relaxin concentrations observed just before parturition may synergize with oestrogen to prevent premature stimulation of uterine contractions by oxytocin and prostaglandins.

In species, such as rats, in which progesterone does not inhibit uterine contractions, relaxin may be important in preventing uterine contractions during a major part of pregnancy (Downing and Sherwood, 1985b). In rats, serum relaxin concentrations increase from day 10 of pregnancy, with a surge to maximum concentrations on day 21 , followed by a decline before birth, although serum relaxin concentrations remain high during birth (Sherwood et al., 1980, 1983). During pregnancy, relaxin occurs in serum as three forms $(60 \mathrm{kDa}, 13 \mathrm{kDa}$ and $6 \mathrm{kDa}$ ), the proportions of which change in a consistent manner as pregnancy progresses (Sherwood et al., 1984). Tolerance may occur to varied extents to the different forms of relaxin. The more rapid recovery of uterine sensitivity to relaxin observed after cessation of prolonged infusion of relaxin to oestradiol plus progesterone-treated rats (Downing and Hollingsworth, 1992a) may indicate that combined actions of oestrogen and progesterone also serve to limit the extent of development of tolerance during pregnancy. As oestrogen concentrations increase during late pregnancy (Shaikh, 1971), synergism between relaxin and oestrogen may serve to restrain myometrial activity in the face of increasing contractile stimuli. At term, high oestrogen and relaxin concentrations might be expected to prevent, or limit, myometrial responses to oxytocin and prostaglandins and thus attenuate the strong contractions required to dilate the cervix and expel the fetuses. Development of tolerance to relaxin at term may effectively withdraw relaxin inhibition of uterine contractions, allowing oxytocin and prostaglandins to stimulate parturient activity. In species such as pigs, in which relaxin action on the uterus may be confined to the immediate antepartum period, tolerance to relaxin may not have a significant role. In accordance with this suggestion is the observation that only one form of relaxin is found in serum in pigs during pregnancy (O'Byrne et al., 1989).
It is not known whether development of tolerance to relaxin occurs in other target tissues, or whether it is confined to the uterus. If the latter is the case, development of uterine tolerance may permit parturient myometrial activity and continued relaxin action on the connective tissue of the cervix, pubic ligament and development of mammary tissue.

\section{Conclusion}

Relaxin is a potent inhibitor of uterine contractions, with a rapid onset of action and, once the hormone is cleared from the circulation, the uterus quickly returns to full contractile activity. Although it is yet to be established that the effects of relaxin on uterine contractions are physiologically important in any species, the nature of the inhibition produced by relaxin suggests that the hormone may be necessary for the fine control of uterine contractions, particularly during the immediate antenatal period and parturition. Relaxin may be important in restraining uterine contractions during the period of declining progesterone influence and increasing sensitivity of the myometrium to oxytocin. If, however, further studies support the current findings of an absence of a relaxant action of human relaxin on human uterus (MacLennan and Grant, 1991; Petersen et al., 1991), then its use for prevention of preterm birth may be precluded. As studies on relaxin progress, its potential for therapeutic use clinically and in animal husbandry, both as a uterine relaxant and as a cervical softening agent, will become more apparent.

The authors thank the MRC, the Wellcome Trust and especially Action Research for financial support of our studies and J. Dawkins (Congerstone, Warwickshire) for the supply of sow ovaries.

\section{References}

Abel MH and Hollingsworth M (1986) The effects of long-term infusion of salbutamol, diltiazem and nifedipine on uterine contractions in the ovariectomized, post-partum rat British Journal of Pharmacology 88 577-584

Adelstein RS, Pato MD and Conti MA (1981) The role of phosphorylation in regulating contractile proteins Advances in Cyclic Nucleotide Research 14 361-373

Anderson MB (1984) Bioassay of porcine relaxin components by in vitro inhibition of rat uterine contraction Endocrinology 114 364-368

Anwer K, Hovington JA and Sanborn BM (1989) Antagonism of contractants and relaxants at the level of intracellular calcium and phosphoinositide turnover in the rat uterus Endocrinology 124 2995-3002

Anwer K, Hovington JA and Sanborn BM (1990) Involvement of protein kinase $A$ in the regulation of intracellular free calcium and phosphoinositide turnover in rat myometrium Biology of Reproduction 43 851-859

Bradshaw JMC, Downing SJ, Moffatt A, Hinton JC and Porter DG (1981) Demonstration of some of the physiological properties of rat relaxin Journal of Reproduction and Fertility 63 145-153

Brenner SH, Lessing JB and Weiss G (1984) The effect of in vivo progesterone administration on relaxin inhibited rat uterine contractions American Journal of Obstetrics and Gynecology 148 946-950

Chamley WA and Parkington HC (1984) Relaxin inhibits the plateau potential component of the action potential in the circular myometrium of the rat Journal of Physiology (London) 353 51-65

Chamley WA, Bagoyo MM and Bryant-Greenwood GD (1977) In vitro response of relaxin-treated rat uterus to prostaglandins and oxytocin Prostaglandins 14 763-769 
Cheah SH and Sherwood OD (1980) Target tissues for relaxin in the rat: tissue distribution of injected ${ }^{125}$-labeled relaxin and tissue changes in adenosine $3^{\prime}$ $5^{\prime}$-monophosphate levels after in vitro relaxin incubation Endocrinology 106 1203-1209

Cheah SH and Sherwood OD (1981) Effects of relaxin on in vivo uterine contractions in conscious and unrestrained estrogen-treated and steroid-untreated ovariectomized rats Endocrinology 109 2076-2083

Cole WC and Garfield RE (1986) Evidence for physiological regulation of myometrial gap junction permeability American Joumal of Physiology 251 C411-C420

Conti MA and Adeistein RS (1981) The relationship between calmodulin binding and phosphorylation of smooth muscle myosin kinase by the catalytic subunit of $3^{\prime}: 5^{\prime}$ cAMP-dependent protein kinase Journal of Biological Chemistry 256 3178-3181

Cossum PA, Dwyer KA, Roth M, Chen SA Moffat B, Vandlen R and Ferraiolo BL (1992) The disposition of a human relaxin (hRlx-2) in pregnant and nonpregnant rats Pharmacological Research 9 419-424

Csapo A (1956) Progesterone 'block' American Joumal of Anatomy 98 273-291

Downing SJ and Hollingsworth M (1991) Antagonism of relaxin by glibenclamide in the uterus of the rat in vivo British Journal of Pharmacology $10471-76$

Downing SJ and Hollingsworth M (1992a) Influence of ovarian steroids on myometrial sensitivity and tolerance to relaxin in the rat in vivo: lack of crosstolerance among relaxin, salbutamol and cromakalim Joumal of Endocrinology 135 17-28

Downing SJ and Hollingsworth M (1992b) Interaction between myometrial relaxants and oxytocin: a comparison between relaxin, cromakalim and salbutamol Journal of Endocrinology 134 29-36

Downing SJ and Hollingsworth M (1993) Uptake of relaxin in the uterus and cervix of the rat in vivo: influence of ovarian steroids and tolerance Joumal of Reproduction and Fertility 99 121-129

Downing SJ and Sherwood OD (1985a) The physiological role of relaxin in the pregnant rat. I. The influence of relaxin on parturition Endocrinology 116 $1200-1205$

Downing SJ and Sherwood OD (1985b) The physiological role of relaxin in the pregnant rat. II. The influence of relaxin on uterine contractile activity Endocrinology 116 1206-1214

Downing SJ, Mcllwrath A and Hollingsworth M (1992) Cyclic adenosine $3^{\prime} 5^{\prime}$ monophosphate and the relaxant action of relaxin in the rat uterus in vivo journal of Reproduction and Fertility 96 857-863

Fei DTW, Gross MC, Lofgren JL, Mora-Worms M and Chen AB (1990) Cyclic AMP response to recombinant human relaxin by cultured human endometrial cells - a specific and high throughput in vitro bioassay Biochemical and Biophysical Research Communications 170 214-222

Ginsburg FW, Rosenberg CR, Schwartz M, Colon JM and Goldsmith LT (1988) The effect of relaxin on calcium fluxes in the rat uterus American Journal of Obstetrics and Gynecology 159 1395-1401

Goldsmith LT, Skurnick JH, Wojtczuk AS, Linden M, Kuhar MJ and Weiss G (1989) The antagonistic effect of oxytocin and relaxin on rat uterine segment contractility American Joumal of Obstetrics and Gynecology 161 1644-1649

Hamilton TC, Weir SW and Weston AH (1986) Comparison of the effects of BRL34915 and verapamil on electrical and mechanical activity in rat portal vein British Journal of Pharmacology 88 103-111

Hollingsworth M, Amédée T, Edwards D, Mironneau J, Savineau JP, Small RC and Weston AH (1987) The relaxant action of BRL34915 in rat uterus British Journal of Pharmacology 91 803-813

Hsu CJ and Sanborn BM (1986) Relaxin treatment alters the kinetic properties of myosin light chain kinase activity in rat myometrial cells in culture Endocrinology 118 499-505

Hsu CJ, McCormack SM and Sanborn BM (1985) The effect of relaxin on cyclic adenosine $3^{\prime}-5^{\prime}$-monophosphate concentrations in rat myometrial cells in culture Endocrinology 116 2029-2035

Hughes SJ, Downing SJ and Hollingsworth M (1992) Relaxin, a potassium channel opener in the isolated rat uterus? British Journal of Pharmacology 106 $80 \mathrm{P}$

Johansson SRM and Andersson RGG (1980) Effects of $\beta$-adrenergic agonists on rat uterine motility and CAMP level in vivo Acta Pharmacologica et Toxicologica $475-10$

Johansson SRM and Andersson RGG (1981) Mechanisms of $\beta$-adrenergic desensitization in rat myometrium Acta Pharmacologica et Toxicologica 49 241-247

Judson JG, Pay S and Bhoola KD (1980) Modulation of cyclic AMP in isolated rat uterine slices by porcine relaxin Journal of Endocrinology 87 153-159
Kemp B and Niall HD (1981) Effect of relaxin on the cAMP-dependent protein kinase in rat uterus. In Relaxin pp 273-275 Eds GD Bryant-Greenwood, HD Niall and FC Greenwood. Elsevier/North Holland, New York

Kramer SM, Gibson UEM, Fendly BM, Mohler MA, Drolet DW and Johnston PD (1990) Increase in cyclic AMP levels by relaxin in newborn rhesus monkey uterus cell culture In vitro Cellular and Developmental Biology 26 647-656

Lao-Guico-Lamm M and Sherwood OD (1988) Monoclonal antibodies specific for rat relaxin. II. Passive immunization with monoclonal antibodies throughout the second half of pregnancy disrupts birth in intact rats Endocrinology $1232479-2485$

Lefkovitz RJ, Hausdorff WP and Caron MG (1990) Role of phosphorylation in desensitization of the $\beta$-adrenoceptor Trends in Pharmacological Sciences 11 190-194

Levitzki A (1986) $\beta$-Adrenergic receptors and their mode of coupling to adenylate cyclase Physiological Reviews 66 819-854

McGovern PG, Goldsmith LT, Schmidt CL, Von Hagen S, Linden M and Weiss G (1992) Effects of endothelin and relaxin on rat uterine segment contractility Biology of Reproduction 46 680-685

MacLennan AH and Grant P (1991) Human relaxin: in vitro response of human and pig myometrium Journal of Reproductive Medicine 36 630-634

Maclennan AH, Grant P, Ness D and Down A (1986) Effect of porcine relaxin and progesterone on rat, pig and human myometrial activity in vitro Journal of Reproductive Medicine 31 43-49

McMurtry JP, Kwok SCM and Bryant-Greenwood GD (1978) Target tissues for relaxin identification in vitro with ${ }^{125}$-labelled porcine relaxin Journal of Reproduction and Fertility 53 209-216

Mercado-Simmen RC, Bryant-Greenwood GD and Greenwood FC (1980) Characterization of the binding of ${ }^{125} \mathrm{I}$-relaxin to rat uterus Journal of Biological Chemistry 255 3617-3623

Mercado-Simmen RC, Bryant-Greenwood GD and Greenwood FC (1982a) Relaxin receptor in the rat myometrium: regulation by estrogen and relaxin Endocrinology $110220-226$

Mercado-Simmen RC, Goodwin B, Veno MS, Yamamoto SY and BryantGreenwood GD (1982b) Relaxin receptors in the myometrium and cervix of the pig Biology of Reproduction 26 120-128

Nara BS, Welk FA, Rutherford JE, Sherwood OD and First NL (1982) Effect of relaxin on parturition and frequency of live births in pig Journal of Reproduction and Fertility 66 359-365

Nishikori K, Weisbrodt NW, Sherwood OD and Sanborn BM (1983) Effects of relaxin on rat uterine myosin light chain kinase activity and myosin light chain phosphorylation Journal of Biological Chemistry 258 2468-2474

Noack T, Deitmer P, Edwards G and Weston AH (1992) Potassium channel modulation in rat portal vein by ATP depletion: a comparison with the effects of levcromakalim (BRL38227) British joumal of Pharmacology 107 945-955

O'Byrne EM, Tabachnik M, Anderson LL and Steinetz BG (1989) Characterization of the circulating form of porcine relaxin: biological activity and terminal amino acids Endocrinology 124 2920-2927

Osa T, Inoue H and Okabe K (1991) Effects of porcine relaxin on contraction, membrane response and cyclic AMP content in rat myometrium in comparison with the effects of isoprenaline and forskolin British Journal of Pharmacology 104 950-960

Osheroff PL, Ling VT, Vandlen RL, Cronin MJ and Lofgren JA (1990) Preparation of biologically active ${ }^{32} \mathrm{P}$-labeled human relaxin: displaceable binding to rat uterus, cervix and brain Journal of Biological Chemistry 265 9396-9401

Osheroff PL, Cronin MJ and Lofgren JA (1992) Relaxin binding in the rat heart atrium Proceedings of the National Academy of Sciences USA 89 2384-2388

Petersen LK, Svane D, Uldbjerg N and Foreman A (1991) Effects of human relaxin on isolated rat and human myometrium and uteroplacental arteries Obstetrics and Gynecology $\mathbf{7 8} 757-762$

Piper I, Minshall E, Downing SJ, Hollingsworth M and Sadraei H (1990) Effects of several potassium channel openers and glibenclamide on the uterus of the rat British Journal of Pharmacology $101901-907$

Porter DG (1982) Unsolved problems of relaxin's physiological role Annals of the New York Academy of Sciences 380 151-162

Porter DG and Challis JRG (1974) Failure of high uterine concentrations of progesterone to inhibit myometrial activity in vivo in the postpartum rat Journal of Reproduction and Fertility 39 157-162

Porter DG and Watts AD (1985) Relaxin and progesterone are myometrial inhibitors in the ovariectomized, non-pregnant mini-pig Journal of Reproduction and Fertility 76 205-213

Porter DG, Downing SJ and Bradshaw JMC (1979) Relaxin inhibits spontaneous and prostaglandin-driven myometrial activity in anaesthetized rats Journal of Endocrinology 83 183-192 
Porter DG, Downing SJ and Bradshaw JMC (1981a) Inhibition of oxytocin- or prostaglandin $\mathrm{F}_{20}$-driven myometrial activity in the rat is oestrogen-dependent Journal of Endocrinology 89 399-404

Porter DG, Lye SJ, Bradshaw JMC and Kendall JZ (1981b) Relaxin inhibits myometrial activity in the ovariectomized non-pregnant ewe Journal of Reproduction and Fertility $61409-414$

Quast U and Cook NS (1988) Moving together: $\mathrm{K}^{+}$channel openers and ATP-sensitive $\mathrm{K}^{+}$channels Trends in Pharmacological Sciences 10 431-435

Rao MR and Sanborn BM (1986) Relaxin increases calcium efflux from rat myometrial cells in culture Endocrinology 119 435-437

Reinig JW, Daniel LN, Schwabe C, Gowan LK, Steinetz BG and O'Byrne EM (1981) Isolation and characterization of relaxin from the sand tiger shark (Odontaspis taurus) Endocrinology 109 537-543

Rudzik AD and Miller JW (1962a) The mechanism of uterine inhibitory action of relaxin-containing ovarian extracts Joumal of Pharmacology and Experimental Therapeutics 138 82-87

Rudzik AD and Miller JW (1962b) The effect of altering the catecholamine content of the uterus on the rate of contractions and the sensitivity of the myometrium to relaxin Joumal of Pharmacology and Experimental Therapeutics 138 88-95

St-Louis J (1981) Relaxin inhibition of $\mathrm{KCl}$-induced uterine contractions in vitro: an alternative bioassay Canadian Journal of Physiology and Pharmacology 59 $507-512$

St-Louis J (1982) Pharmacological studies on the action of relaxin upon KCl-contracted rat uterus Pharmacology 25 327-337

Sanborn BM, Kuo HS, Weisbrodt NW and Sherwood OD (1980) The interaction of relaxin on the rat uterus. I. Effect on cyclic nucleotide levels and spontaneous contractile activity Endocrinology 106 1210-1215

Sanborn BM, Weisbrodt NW and Sherwood OD (1981) Evidence against an obligatory role of catecholamine release in the effects of relaxin on the rat uterus Biology of Reproduction 24 987-992

Sarosi P, Schmidt CL, Essig M, Steinetz BG and Weiss G (1983) The effect of relaxin and progesterone on rat uterine contractions American Joumal of Obstetrics and Gynecology 145 402-405
Schwabe C and Bullesbach EE (1990) Relaxin Comparative Biochemistry and Physiology 96B 15-21

Shaikh A (1971) Estrone and estradiol levels in ovarian venous blood from rats during the estrous cycle and pregnancy Biology of Reproduction 5 297-307

Sherwood OD (1988) Relaxin. In The Physiology of Reproduction Vol 1 Pp 585-673 Eds E Knobil and JD Neill. Raven Press, New York

Sherwood OD, Chang CC, BeVier GW and Dziuk PJ (1975) Radioimmunoassay of plasma relaxin levels throughout pregnancy and at parturition in the pig Endocrinology 94 834-837

Sherwood OD, Crnekovic VE, Gordon WL and Rutherford JE (1980) Radioimmunoassay of relaxin throughout pregnancy and during parturition in the rat Endocrinology $107691-698$

Sherwood OD, Downing SJ, Golos TG, Gordon WL and Tarbell MK (1983) Influence of light:dark cycle on antepartum serum relaxin and progesterone immunoactivity levels and on birth in the rat Endocrinology 113 997-1003

Sherwood OD, Key RH, Tarbell MK and Downing SJ (1984) Dynamic changes of multiple forms of serum immunoactive relaxin during pregnancy in the rat Endocrinology 114 806-813

Steinetz BG, O'Byrne EM, Weiss G and Schwabe C (1982) Bioassay methods for relaxin: uses and pitfalls Advances in Experimental Medicine and Biology 143 79-104

Watts AD, Flint APF, Foxcroft GR and Porter DG (1988) Plasma steroid, relaxin and dihydro-keto-prostaglandin $F_{2 u}$ changes in the minipig in relation to myometrial electrical and mechanical activity in the prepartum period Journal of Reproduction and Fertility 83 553-564

Wiqvist $\mathbf{N}$ (1959) Desensitizing effect of exo- and endogenous relaxin on the immediate uterine response to relaxin Acta Endocrinologica 32 (Supplement 46) 3-14

Wiqvist N and Paul KG (1958) Inhibition of the spontaneous uterine motility in vitro as a bioassay of relaxin Acta Endocrinologica 29 135-146

Yang S, Rembiesa B, Bullesbach EE and Schwabe C (1992) Relaxin receptors in mice: demonstration of ligand binding in symphyseal tissues and uterine membrane fractions Endocrinology 130 179-185 